\title{
Board Structure of Corporate Organizations and Earnings Management: Does Size and Independence of Corporate Boards Matter for Nigerian Firms?
}

\author{
Abel Oghenevwoke $\operatorname{Ideh}^{1}$, Edirin Jeroh ${ }^{2} \&$ Orits Frank Ebiaghan ${ }^{3}$ \\ ${ }^{1}$ Department of Accounting and Finance, Delta State University, Abraka, Nigeria \\ Correspondence: Edirin Jeroh, Department of Accounting and Finance, Delta State University, Abraka, Nigeria.
}

Received: August 15, 2020

Accepted: October 18, 2020

Online Published: January 9, 2021

doi:10.5430/ijfr.v12n1p329

URL: https://doi.org/10.5430/ijfr.v12n1p329

\begin{abstract}
The relationship subsisting between board structure of corporate organizations and earnings management has attracted several concerns particularly to regulatory agencies, management, accounting practitioners and researchers alike. Therefore, this study, examined the extent to which board independence and size influence the level of earnings management of publicly quoted Nigerian firms. For this purpose, the adoption of the International Financial Reporting Standards (IFRS) and the age of firms were introduced as mediating variables. Secondary data were however pooled from the financial statements of ninety-two (92) firms cutting across ten (10) industrial sectors from 2007-2018 (12 years). The regression analysis amidst other relevant statistical techniques was adopted to analyze the collated pooled data. Evidence from our result indicates that with the introduction of IFRS adoption and firm age as mediating variables, the $\mathrm{F}_{\text {cal }}$ obtained was $1.72(\mathrm{p}$-value $=0.1424)$, thus indicating that the size of boards and the presence of independent directors (board independence) in corporate boards could not significantly influence the level of earnings management in Nigerian firms. We therefore recommend that in order to regulate managements' opportunistic behavior/earnings management, regulators and stakeholders who are charged with the task of performing oversight functions on the activities of management should lay more emphasis on ensuring that preparers of financial statements fully comply with the provisions of IFRS and other regulatory requirements for financial reporting.
\end{abstract}

Keywords: earnings management, board size, board independence, opportunistic behaviour, board of directors, IFRS

JEL Classification: G34; G38; M41

\section{Introduction}

Organizations strive to be effective in maintaining improved levels of performance and enhanced firm value over time. In doing this, several factors are repeatedly considered. Prominent among these factors are Board, and Chief Executive officer (CEO) attributes, ownership structure, information asymmetries, financial attributes, firm size, strategic policies, and a host of others (Brennan, 2006; Jeroh, 2020a). In view of this, prior studies have therefore drawn a link between the presence of efficient corporate boards and firms' performance with particular reference to the moderation of cost of capital, intensification of firm value and the enhancement of risk controls, which invariably lends credence to the quality of financial reporting, sustainable growth and the reduction of opportunistic behavior of managers (Akpan \& Amran, 2014; Obigbemi, Omolehinwa, Mukoro, Ben-Caleb \& Olusanmi, 2016).

Within most organizational setting, the structure of corporate boards constitutes a fundamental attribute that exemplifies the core boundary of in-house governance. This could be the reason why Arosa, Iturralde and Maselda (2013) averred that firms' aggregate performances could be substituted with changes in their respective board structures. No doubt, top level strategic decisions taken by corporate boards have immediate and long term direct and/or indirect effect on the entire operations/activities of reporting entities. Although, while we expect that each company's Board of Directors would continue to develop strategic policies and monitor the overall activities of management (Burghleh \& Al-Okdeh, 2020), the fact that corporate managers may still act for personal gains rather than in the interest of shareholders cannot be completely ruled out. In fact, studies had pointed that managers may sometimes be involved in opportunistic actions such as the deliberate alteration of financial statements' contents possibly to conceal the actual economic conditions of companies for private gains or other purposes (Muramiya \& Takada, 2017; Lacina, Lee \& Kim, 2018; Agustia, Muhammad \& Permatasari, 2020; Sianturia, Wahyudi, Pangestuti \& 
Utomo, 2020). Such action of management which may influence contractual outcomes or mislead interested parties as a result of the distortions in the reported earnings of companies, best describes the concept of earnings management (Ubesie, Ogbu \& Mbah, 2019; Dao \& Ngo, 2020).

Earnings management has negative consequences and the concept has in recent time appeared in the front burner of accounting discourse (Okougbo \& Okike, 2015; Priharta \& Rahayu, 2019; Saona \& Muro, 2019; Mostafa \& Ibrahim, 2019; Burghleh \& Al-Okdeh, 2020). It is however believed that through earnings management, the quality of firms' earnings is undermined, thus raising doubts on the credibility of the financial reports of companies.

\subsection{Problem Statement and Research Objective}

Since the structure of corporate boards possibly depicts standard and public images of organizations (Obigbemi et al. 2016), it is expected that efficient boards, with their oversights on managements' activities may reduce earnings management among companies. Notwithstanding, prior research outcomes have remained mixed and contradictory in this regards. For instance, while some studies point that the relationship between earnings management and the size of corporate boards is positive and probably significant (Okougbo \& Okike, 2015; Burghleh \& Al-Okdeh, 2020); other sets of studies have argued that the subsisting relationship between board size and earnings management is either negative and significant (Obigbemi et al. 2016), or not significant (Dao \& Ngo, 2020; Abdelkarim \& Zuriqi, 2020). This current study is therefore motivated by our observation that despite the contradictory results thus far, there is also no clear delineation of probable reasons for the existing conflicting results even when some of the studies were conducted in the same industrial categories, countries, or regions (Zalata, Tauringana \& Tingbani, 2018).

Our argument further stems from the fact that arising from the adoption and implementation of the standard setters' decision which culminated into the wide adoption of the International Financial Reporting Standards (IFRS) for reporting purposes, several corporate governance measures (including board structure variables) may not be significant in defining financial reporting quality or in reducing earnings management by firms. This is because the policy thrust of international/global standards is incumbent on the enhancement of financial reporting quality through the reduction and possible elimination of earnings management within companies (Tsalavoutas \& Dionysiou 2014; Mardini, Crawford \& Power, 2012). Consequently, to clear existing doubts or conflicts arising from the outcomes of prior studies, it becomes pertinent to carry out an empirical investigation which this paper attempts to satisfy by examining the relationship between board structure measures (specifically, size and independence) and earnings management among Nigerian firms. To distinguish this study from other prior Nigerian studies, particular consideration was given to examining the trends and movements of the variables of interest in periods before and after the implementation of IFRS in the country. We made efforts to find out whether or not; the adoption and implementation of IFRS reinforced the relationship between board structure measures (size and independence) and earnings management. Towards achieving our aim, this paper is further sectioned as follows: conceptual review and hypothesis development, methodology, results, discussions and conclusion.

\section{Conceptual Review and Hypothesis Development}

\subsection{Conceptualization of Earnings Management}

With the current changes in the strategic architecture of companies (Jeroh, 2020b), several concerns have been raised about the happenings in organizations with specific interest on the activities of management. Since the responsibility of providing reliable and valuable information to a variety of users rests on the management of companies, the quality of financial reports can thus be weighed by assessing the level of involvement of management in opportunistic behavior or earnings management. No doubt, the concept "earnings management" has become one major issue of concern to management, accounting practitioners and accounting researchers alike. Accordingly, earnings management has been defined by prior studies to include intentional misapplication and abuse of accounting standards or a deviation from normal business cycles, practices and operations with the opportunistic aim of misrepresenting the reported earnings of companies with a view to influencing contractual outcomes and mislead unsuspecting stakeholders (Madhogarhia, Sutton \& Kohers, 2009; Li, 2019a; Campa, 2019; Li, 2019b; Yang \& Abeysekera, 2019; Sianturia, Wahyudi, Pangestuti \& Utomo, 2020).

As observed, in a bid to accomplish specific targets through the management of reported earnings, some managers avoid or under report losses and in some other cases, the operating policies of the companies are changed to obtain short-term targets at the expense of the companies' interests (Al Saedi, 2018; Chan, Li \& Lin, 2019; Pappas, Walsh \& $\mathrm{Xu}, 2019)$. This is why Obigbemi et al. (2016), described earnings management as managements' deliberate effort, targeted at obtaining a desired amount of earnings through several possible means. Several incentives for managers' 
opportunistic behavior or earnings management have been identified; but the most common among them as noted by prior studies is income smoothing (Dao \& Ngo, 2020).

Noteworthy, earnings management could practically be done through two major ways - accounting methods (inventory valuation techniques, accounting policy and estimation technique/approach etc) and the management of accruals (Priharta \& Rahayu, 2019; Abdelkarim \& Zuriqi, 2020). Worth mentioning is the fact that whatever method adopted, the management of organizations who were employed as agents to serve as stewards on behalf of the shareholders are practically the ones involved in such acts of earnings management.

In Nigeria, efforts by the relevant regulatory authorities to either curb or eliminate earnings management saw the mandatory requirement for entities to adopt the global sets of reporting standards (International Financial Reporting Standards - IFRSs) and the continuous updates/revisions of existing corporate governance codes. Failure to fully comply with the provisions of IFRSs and the governance codes attracts appropriate sanctions. Since the main justification for appointing and constituting corporate boards for listed entities lies basically on the need to have an independent body charged with the responsibility of monitoring management's activities; this current study therefore sets out to examine whether the structure of corporate boards (with emphasis on size and independence) matters in reducing earnings management amongst firms, especially when companies have now adopted IFRS in reporting their respective transactions. The study is also interested in knowing whether or not, the adoption of IFRS reinforces the link between board structure measures and earnings management.

\subsection{Board Characteristics}

\subsubsection{Board Size}

The Board can be classified as a firm's highest echelon of control which is saddled with the onerous responsibility of effectively managing its activities. The task of monitoring financial statements' content and quality while monitoring the behavior and activities of senior managers in organizations rests on the hands of corporate boards (Okougbo \& Okike, 2015). Thus, the membership of corporate boards goes a large extent to determine the soundness or otherwise of its decisions. As provided by the applicable governance codes for corporate organizations in Nigeria, board sizes of firms should range from a minimum of five (5) members to a maximum of 20 members for banks and discount houses; and 15 members for other categories of public companies (CBN 2014; Obigbemi et.al., 2016). Though with contradictory outcomes in terms of magnitude and directions, there are empirical evidence suggesting either the existence, or as found in other cases, the non existence of a relationship between the sizes of corporate boards and earnings management (Abed, Al-Attar \& Suwaidan, 2012; Abdelkarim \& Zuriqi, 2020). For instance, studies have reported the existence of negative correlation between earnings management and board size (Abed, Al-Attar \& Suwaidan, 2012); whereas, subsisting evidence from the literature also indicates the existence of a positive association between earnings management and board size (Rahman \& Ali, 2006). Despite these contradictions, an argument from other schools of thought is that earnings management and board size has no subsisting relationship (Hashim \& Devi, 2008; Gulzar \& Wang, 2011).

In this current study however, while we support arguments that the size/membership of identified corporate boards may possibly influence the soundness and monitoring capabilities of such boards; one contributory factor that partly aroused our current interest is that prior studies have not accounted for the possible reasons for their contradictory findings. Again, whether board size would still be relevant in explaining management's involvement in opportunistic behavior/earnings management in an era where the adoption of IFRS may have possibly blocked the likely loopholes that supports acts of earnings management has not been clearly examined in the Nigerian context.

\subsubsection{Board Independence}

The repeated calls for corporate managers to be more disciplined and highly monitored came after the outburst of worrisome high profile financial scandals (Jeroh, 2020b) which involved corporate giants within and outside Nigeria. Ignited by the global and domestic concern of financial reporting quality of firms, SEC $(2003,2011)$ through her Corporate Governance Codes (CGCs) provides that companies should constitute corporate boards that are more independent in their structure. This idea of having independent boards is birthed on the notion that where a board has higher presence or number of non-executive directors, who ordinarily ought to be independent of the companies' managers/executive directors, such boards are expected to be generally objective and may possibly be independent with regards to their monitoring and/or oversight functions (Bello, 2011). According to Obigbemi et al. (2016), the CGCs in Nigeria require the composition of corporate boards with a mix of both executives and non-executive directors. Board independence is therefore measured with reference to the number of non-executive directors in identified corporate boards by specifically weighing its proportion to total board size. Thus, prior studies (Müller, 2014; 
Fuzi, Halim \& Julizaerma, 2016; Zabri, Ahmad \& Wah, 2016; Alshetwi, 2017; Rashid, 2018; Naciti, 2019) have used the terms "independent directors", "outside directors" and "non-executive directors" interchangeably.

Notwithstanding, board independence describes the intensity of independent/non-executive directors presence in corporate boards (Prabowo \& Simpson, 2011; Zabri et al., 2016; Rashid 2018). No doubt, the level of independence of corporate boards largely determines the extent of corporate boards' abilities to make independent judgments irrespective of possible conflicting interests between those of shareholders and the management team of their respective organizations (Alshetwi, 2017; Abdelkarim \& Zuriqi, 2020). Apparently, the level of objectivity and monitoring capabilities of corporate boards could possibly be strengthened through the constitution of boards with higher proportion of independent/non-executive directors who by their very nature, are external to the organization and less likely to be influenced by companies' management or their representatives ( $\mathrm{Li}$, Lu, Mittoo \& Zhang, 2015; Fuzi et al., 2016). This notion has spurred research interests geared towards unveiling the link between board independence and variables like performance, CSR disclosure, reporting quality and by extension, earnings management (Jaggi, Leung \& Gul, 2009; Gulzar \& Wang, 2011; Busirin, Azmi \& Zakaria, 2015; Chen, Cheng \& Wang, 2015; Rashid, 2018; Naciti, 2019). Specifically, a good number of studies that examined the association between the independence of corporate boards and earnings management have so far reported contradictory findings. In this light, while Gulzar \& Wang (2011) could not find any link between the independence of corporate boards and earnings management, other studies documented the existence of a relationship between both variables, though with conflicting directions of the relationship (Jaggi, Leung \& Gul, 2009; Chen, Cheng \& Wang, 2015; Busirin, Azmi \& Zakaria, 2015). Notwithstanding, the moderating effect which IFRS adoption may have on the relationship between board attributes (such as independence) and earnings management among Nigerian firms has received little or practically no attention.

As observed from the arguments in the literature (Chen, Cheng \& Wang, 2015), the prevailing information environment of companies may possibly reinforce the relationship between earnings management and the level of independence maintained by corporate boards. If this argument subsists, this study's concern therefore stems from the belief that with the current information environment of financial reporting in Nigeria and most parts of the world, efforts at reducing earnings management should rather be tilted more towards compliance with the provisions of IFRS and not the structure of boards. This belief results from the claim that IFRS were designed to reduce irregularities in reporting practices and enhance integrity and comparability in financial reporting. On this note, in order to unveil a possible reason for the conflicting results of prior studies, this current study evaluated the moderating effect which IFRS adoption may have on the relationship between board independence and earnings management among publicly quoted companies in Nigeria. With the aforesaid, we thus hypothesize that:

$H_{O}$ : $\quad$ following the adoption of IFRS, board size and independence does not have significant relationship with earnings management amongst publicly quoted companies in Nigeria.

\section{Research Methods}

\subsection{Design, Sampling and Data}

This study was conducted using the ex-post facto design. Secondary data were therefore pooled from the financial reports of ninety-two (92) firms cutting across ten (10) industrial categories. The reliance on pooled data is justified by the researchers' intentional effort to refrain from incorporating survivor bias in the sampling procedure. The sample was nonetheless obtained through the purposive sampling technique with specified unbiased filters namely: (1) companies must be publicly quoted and must be in business as at $31^{\text {st }}$ December, 2018 (2) must report data for the study's variables for at least 2 years within the study period. Pooled data were sourced within the study period which spanned from 2007-2018 (12 years). The sourced data were further subjected to diagnostic tests and post estimations by means of appropriate statistical techniques.

\subsection{Variables - Measurement and Nomenclature}

Table 1. Nomenclature and measurement of variables

\begin{tabular}{|c|c|c|}
\hline Variables & Labels & Measurement \\
\hline $\begin{array}{l}\text { Earnings } \\
\text { Management }\end{array}$ & EarnMgt & $\begin{array}{l}\text { Discretionary accruals based on the residuals of Total Accruals from the Modified } \\
\text { Jones model }\left(\mathrm{TA} / \mathrm{A}_{\mathrm{t}-1}=\beta_{0}\left(1 / \mathrm{A}_{\mathrm{t}-1}\right)+\beta_{1} \mathrm{REV} / \mathrm{A}_{\mathrm{t}-1}+\beta_{2} \Delta \mathrm{CREV} / \mathrm{A}_{\mathrm{t}-1}+\beta_{3} \Delta \mathrm{DREV} / \mathrm{A}_{\mathrm{t}-1}+\right. \\
\left.\beta_{4} \mathrm{PPE}_{\mathrm{t}-1} / \mathrm{A}_{\mathrm{t}-1}+\varepsilon\right) . \text { Where TA }=\text { Current year's Total Accruals; } 1 / \mathrm{A}_{\mathrm{t}-1}=\text { inverse of } \\
\text { lagged total assets; REV }=\text { revenue for current year; } \Delta \mathrm{CREV}=\text { changes in cash } \\
\text { accompanying revenue; } \Delta \mathrm{DREV}=\text { changes in sales and debtors; PPE } \mathrm{t}_{\mathrm{t}-1}=\text { lagged }\end{array}$ \\
\hline
\end{tabular}




\begin{tabular}{lll}
\hline $\begin{array}{l}\text { Board Size } \\
\begin{array}{l}\text { Board } \\
\text { Independence }\end{array}\end{array}$ & $\begin{array}{l}\text { Bodsz } \\
\text { Bodind }\end{array}$ & $\begin{array}{l}\text { property plant \& equipment; } \varepsilon=\text { error term. } \\
\text { Number of persons in corporate boards (size of board membership). } \\
\text { Proportion of Non-Executive Directors to Total Board Members. }\end{array}$ \\
$\begin{array}{l}\text { IFRS } \\
\text { Adoption }\end{array}$ & IFRSad & $\begin{array}{l}\text { Dummy variable of 1 for periods in which financial statements of companies were } \\
\text { prepared using IFRS and 0 otherwise. }\end{array}$ \\
$\begin{array}{l}\text { Firm Age } \\
\text { Number of years in which companies have been in existence since its year of first } \\
\text { listing on the floor of the stock exchange. }\end{array}$ \\
\hline
\end{tabular}

\subsection{Analytical Techniques}

The regression analysis amidst other relevant statistical techniques was adopted to analyze the collated data. Specifically, descriptive statistics, correlation analysis and the OLS techniques were employed. Post estimations for multicollinearity and heteroscedasticity were done using Cameron \& Trivedi's (C-T) decomposition IM-test, Szroeter's test and the Variance Inflation Factor (VIF) tests respectively.

\subsection{Model Specification}

We built a direct relationship between earnings management and the explanatory variables (board size, board independence) as mediated by IFRS adoption and the age of firms. Based on this relationship, the empirical model of this study is specified in the following equation

$$
\text { EarnMgt }_{i t}=\beta_{0} \text { Bodsz }_{i t}+\beta_{1} \text { Bodind }_{i t}+\beta_{2} \text { IFRSad }_{i t}+\beta_{3} A G E_{i t}+\beta_{4}+\varepsilon
$$

Where: ${ }_{i t}=$ company $i$ in a given year $t$.; $\mathrm{B}_{0}, \mathrm{~B}_{1}, \mathrm{~B}_{2}, \mathrm{~B}_{3}$ and $\mathrm{B}_{4}$ are beta coefficients.

\section{Results and Discussions}

\subsection{Descriptive Statistics and Correlation Result}

Table 2. Descriptive data

\begin{tabular}{lccccc}
\hline Variables & Obs & Min & Max & Mean & Std Dev. \\
\hline EarnMgt & 939 & -3.64 & 1.71 & -2.95 & 0.22 \\
Bodsz & 939 & 4 & 23 & 8.95 & 2.75 \\
Bodind & 939 & 0 & 1 & 0.66 & 0.16 \\
IFRSad & 939 & 0 & 1 & 0.64 & 0.48 \\
AGE & 939 & 4 & 66 & 34.95 & 14.21 \\
\hline
\end{tabular}

Indications from the results for descriptive statistics (see table 1) is that total observations for all variables was 939. This means that no omission was recorded for any variable. The residuals obtained to measure earnings management ranged approximately from -3.64 to 1.71 with a very low average value of -2.95 . The relatively low mean value for EarnMgt may lead to the engagement of management team on some opportunistic actions. On its part, Bodsz ranged from 4 to 23 with an average value of 8.95 over the period. This means that despite high compliance with the governance codes for companies in Nigeria, some companies still have board sizes below the minimum required number of 5; just as some companies' board sizes are larger than the maximum of 15 and 20, depending on the nature of the company. Bodind which ranged from 0 to 1 recorded a mean value of approximately $0.66(66 \%)$. Impliedly, despite the existence of companies' corporate boards without the presence of independent/non-executive directors, the level of independence of most corporate boards in Nigeria is above 50\%. Firm age (AGE) ranged from 4 to 66 indicating that all sampled companies have operated for at least 4 years after their respective listing year. The low standard deviation recorded for the dependent and explanatory variables shows that the data may have been normally distributed with the presence of insignificant or no outliers. 
Table 3. Correlation matrix

\begin{tabular}{lccccc}
\hline Variables & EarnMgt & Bodsiz & Bodind & IFRSad & AGE \\
\hline EarnMgt & 1.0000 & & & & \\
Bodsiz & 0.0484 & 1.0000 & & & \\
Bodind & 0.0734 & 0.0921 & 1.0000 & & \\
IFRSad & -0.0065 & -0.0036 & -0.0065 & 1.0000 & \\
AGE & 0.0189 & 0.0618 & 0.0586 & 0.0488 & 1.0000 \\
\hline
\end{tabular}

Furthermore, we present the result of the correlation matrix in Table 3 which displays the direction of relationship among the variables. As observed, board size, board independence and firm age recorded positive association with earnings management whereas, IFRS adoption recorded negative coefficient with earnings management. This means that a further increase in the sizes and level of independence of corporate boards by one unit will result to 0.0484 and 0.0734 unit increase in indications that management will be interested in managing earnings. Also, the coefficients recorded between pairs of independent variables were far below the maximum threshold of 0.70 . Note that the dataset for any study does not have concern for multicollinearity where the coefficients recorded for pairs of independent variables are below the maximum threshold (Sianturi et al. 2020; Jeroh, 2020a).

\subsection{Regression Analysis of Earnings Management and Board Structure}

After assessing the statistical association between earnings management (as dependent variable) and board size and independence (independent variables), with IFRS adoption and firm age as mediating variables, post estimations were conducted and the results are presented in Table 4.

Reported in Table 4 are results for homoscedasticity and heteroscedasticity using Szroeter test, VIF test and Cameron \& Trivedi's decomposition of IM-test. As observed, the Chi2 values reported for all variables under the Szroeter test ranged from 8.95 (Bodind) to 174.19 (AGE). The p-values recorded were all significant at 1\%. Additionally, we reported a mean VIF of 1.01 with tolerance levels ranging between 0.9883 (Bodsz) to 0.9975 (IFRSad). These results are clear indications that the data used in this study are free from multicollinearity concerns. Also, judging from the result of the Szroeter's test we accept the hypothesis of the existence of variance monotonic in our variable. This position is further confirmed with the result of the C-T decomposition of IM-test. Overall, with these results in Table 4, the fitness of our model is confirmed and this further gives credence to the reliability of the findings/results discussed in this study.

Table 4. Post estimations

\begin{tabular}{lccccc}
\hline Variables & \multicolumn{2}{c}{ Variance Inflation Factor } & \multicolumn{3}{c}{ Szroeter Test } \\
\cline { 2 - 6 } & VIF & $\mathbf{1 / V I F}$ & Chi2 & Df & Unadj. p-values \\
Bodsz & 1.01 & 0.9883 & 36.22 & 1 & $0.0000^{*}$ \\
Bodind & 1.01 & 0.9886 & 8.95 & 1 & $0.0028^{*}$ \\
AGE & 1.01 & 0.9909 & 174.19 & 1 & $0.0000^{*}$ \\
IFRSad & 1.00 & 0.9975 & 145.9 & 1 & $0.0000^{*}$ \\
Mean VIF & $\mathbf{1 . 0 1}$ & & & & \\
& & & & & \\
C-T Decomposition of IM-test & & $\mathbf{C h i 2}$ & $\mathbf{D f}$ & $\mathbf{p - v a l u e s}$ \\
Hettest & & & 16.97 & 13 & 0.2006 \\
Skewness & & & 4.29 & 4 & 0.3676 \\
Kurtosis & & & 1.22 & 1 & 0.2696 \\
Total & & & $\mathbf{2 2 . 4 6}$ & $\mathbf{1 8}$ & $\mathbf{0 . 2 1 1 2}$ \\
\hline
\end{tabular}


With respect to our regression analysis and test of hypothesis, the results from Table 5 revealed a positive coefficient for measures of board structure while AGE recorded a negative coefficient. Given the results of the $t_{\text {-stat }}$, it is obvious that with a value of 2.10 and a p-value of 0.036 , independent of other variables, Bodind could significantly influence earnings management. This is not the case for Bodsz which recorded $\mathrm{t}$-value of 1.26 ( $\mathrm{p}$-value $=0.208$ ). However, with the mediation of IFRSad and AGE, we observed that the $F_{\text {cal }}$ stood at 1.72 with a p-value of 0.1424 . With this result, we could not reject the hypothesis that following the adoption of IFRS, board size and independence does not have significant relationship with earnings management amongst publicly quoted companies in Nigeria. This therefore goes a long way to suggest that overtime (age consideration), where the compliance to regulatory framework for financial reporting (IFRS adoption) is highly enforced, the size of corporate boards or their level of independence play an insignificant role in reducing the tendencies of opportunistic behavior of management. The above outcome supports the position of Gulzar and Wang (2011) who posit that board independence does not have significant influence on earnings management. Additionally, this current study also find evidence to support the claim that board size may not have significant influence on management's opportunistic behavior (Abed, Al-Attar \& Suwaidan, 2012; Abdelkarim \& Zuriqi, 2020).

Table 5. Result of model evaluation and test of hypothesis

\begin{tabular}{lccccc}
\hline $\begin{array}{l}\text { Variables \& } \\
\text { Statistics }\end{array}$ & Coeff & Std.Err & $\mathbf{t}_{\text {-stat }}$ & $\mathbf{P}>|\mathbf{t}|$ & Obs \\
\hline Bodsz & 0.0033 & 0.0026 & 1.26 & 0.208 & 939 \\
Bodind & 0.0910 & 0.0434 & 2.10 & 0.036 & 939 \\
AGE & -0.0030 & 0.0148 & -0.20 & 0.841 & 939 \\
IFRSad & 0.0002 & 0.0005 & 0.39 & 0.699 & 939 \\
\hline cons & -0.0944 & 0.0398 & -2.37 & 0.018 & \\
& & & & & \\
F $_{\text {cal }}$ & 1.72 & & & & \\
Prob $>$ F $_{\mathbf{R}^{2}}$ & 0.1424 & & & & \\
\hline Adj. $\mathbf{R}^{\mathbf{2}}$ & 0.0073 & & & & \\
\hline
\end{tabular}

\section{Conclusion}

This research focused on assessing whether board size and independence play significant role in explaining levels of managements' involvement in opportunistic behaviour/earnings management. Using 939 firm year observations from a total of 92 publicly quoted companies across 10 industrial categories in Nigeria over 12 years (2007 - 2018), empirical evidence have shown that over time, following the adoption of IFRS, the size of corporate boards or their level of independence does not play significant role in reducing the tendencies for opportunistic behaviour of management. This means that earnings management in companies would better be reduced through the enforcement of full compliance with the provisions of IFRS. While we agree from our results that in the absence of sound reporting standards like IFRS, board independence could significantly influence earnings management; the same could not be said for board size. With the outcome from our analysis, we could not reject the study's hypothesis. Impliedly, following the adoption of IFRS as the basis of financial reporting by publicly quoted firms, the sizes of corporate boards and their level of independence no longer play significant roles in reducing managerial opportunistic behaviour/earnings management. This explains why studies may have recorded mixed findings in the past. Thus, where companies exist in economies with better information environment and possibly sound regulatory and reporting framework, the results on the relationship between board structure variables will not be the same as those existing in dissimilar environment. Our study therefore contributes to the plethora of literature on earnings management and measures of corporate governance, but is distinguished in its ability to underscore the possible reason for the conflicting results of prior studies in this area. 


\subsection{Recommendation}

Based on this study's outcome, we therefore recommend that in order to regulate managements' opportunistic behavior/earnings management, regulators and stakeholders who are charged with the task of performing oversight functions on the activities of management should lay more emphasis on ensuring that preparers of financial statements fully comply with the provisions of IFRS and other regulatory requirements for financial reporting.

\section{References}

Abdelkarim, N., \& Zuriqi, K. (2020). Corporate governance and earnings management: Evidence from listed firms at Palestine exchange. Asian Economic and Financial Review, 10(2), 200-217. https://doi.org/10.18488/journal.aefr.2020.102.200.217

Abed, S., Al-Attar, A., \& Suwaidan, M. (2012). Corporate governance and earnings management: Jordanian evidence. International Business Research, 5(1), 216-225. https://doi.org/10.5539/ibr.v5n1p216

Agustia, D., Muhammad, N. P. A., \& Permatasari, Y. (2020). Earnings management, business strategy, and bankruptcy risk: evidence from Indonesia. Heliyon, 6, 1-9. https://doi.org/10.1016/j.heliyon.2020.e03317

Akpan, E. O., \& Amran, N. A. (2014). Board characteristics and company performance: evidence from Nigeria. Journal of Finance and Accounting, 2(3), 81-89.

Al Saedi, A. A. (2018). Earnings management and its relationship with stock returns: An empirical study on a sample of Qatari listed industrial companies. Academy of Accounting and Financial Studies Journal, 22(5), 1-12.

Alshetwi, M. (2017). The Association between board size, independence and firm performance: Evidence from Saudi Arabia. Global Journal of Management and Business Research (D): Accounting and Auditing, 17(1), 17-28.

Arosa, B., Iturralde, T., \& Maseda, A. (2013). The board structure and firm performance in SMEs: Evidence from Spain. InvestigacionesEuropeas de DirecciónyEconomía de la Empresa, 19(3), 127-135.

Bello, A. (2011). Corporate governance and accounting ethics in Nigeria. Proceeding of the International Conference on Management (ICM), 1591-1608.

Brennan, N. (2006). Boards of directors and firm performance: Is there an expectations gap?. Corporate governance: An International Review, 14(6), 577-593.

Burghleh, M. M. K., \& Al-Okdeh, S. K. (2020). The impact of family ownership concentration on the relationship between the characteristics of board of directors and earnings management. Management Science Letters, 10, 969-978. https://doi.org/10.5267/j.msl.2019.11.014

Busirin, M. F., Azmi, N. A., \& Zakaria, N. B. (2015). How effective is board independence to the monitoring of earnings manipulation?. Procedia Economics and Finance, 31, 462-469. https://doi.org/10.1016/S2212-5671(15)01177-6

Campa, D. (2019). Earnings management strategies during financial difficulties: A comparison between listed and unlisted French companies. Research in International Business and Finance, 50, 457-471. https://doi.org/10.1016/j.ribaf.2019.07.001

CBN. (2014). Code of corporate governance for banks and discount houses in Nigeria. Abuja: Central Bank of Nigeria.

Chan, K., Li, F., \& Lin, T-C. (2019). Earnings management and post-split drift. Journal of Banking \& Finance, 101, 136-146. https://doi.org/10.1016/j.jbankfin.2019.02.004

Chen, X., Cheng, Q., \& Wang, X. (2015). Does increased board independence increase earnings management? Evidence from recent regulatory reforms. Review of Accounting Studies, 20, 899-933. https://doi.org/10.1007/s11142-015-9316-0

Dao, B. T. T., \& Ngo, H. A. (2020). Impact of corporate governance on firm performance and earnings management: A study on Vietnamese non-financial companies. Asian Economic and Financial Review, 10(5), 480-501. https://doi.org/10.18488/journals.aefr.2020.105.480.501

Fuzi, S. F. S., Halim, S. A. A., \& Julizaerma, M. K. (2016). Board independence and firm performance. Procedia Economics and Finance, 37, 460-465. https://doi.org/10.1016/S2212-5671(16)30152-6

Gulzar, A., \& Wang, Z. (2011). Corporate governance characteristics and earnings management: Empirical evidence from Chinese listed firms. International Journal of Accounting and Financial Reporting, 1(1), 133-151. 
Hashim, H. A., \& Devi, S. S. (2008). Board independence, CEO duality and accrual management: Malaysian evidence. Asian Journal of Business and Accounting, 1(1), 27-46.

Jaggi, B., Leung, S., \& Gul, F. (2009). Family control, board independence and earnings management: Evidence based on Hong Kong firms. Journal of Accounting and Public Policy, 28(4), 281-300. https://doi.org/10.1016/j.jaccpubpol.2009.06.002

Jeroh, E. (2020a). Corporate financial attributes and the value of listed financial service firms: The Nigerian evidence. Academy of Accounting and Financial Studies Journal, 24(2), 1-13.

Jeroh, E. (2020b). Firms' attributes, corporate social responsibility disclosure and the financial performance of listed companies in Nigeria. Asian Economic and Financial Review, 10(6), 727-743. https://doi.org/10.18488/journal.aefr.2020.106.727.743

Lacina, M., Lee, B. B., \& Kim, D. W. (2018). Benford's Law and the effects of the Korean financial reforms on cosmetic earnings management. Journal of International Accounting, Auditing and Taxation, 30, 2-17. https://doi.org/10.1016/j.intaccaudtax.2017.12.002

Li, K., Lu, L., Mittoo, U. R., \& Zhang, Z. (2015). Board independence, ownership concentration and corporate performance - Chinese evidence. International Review of Financial Analysis, 41, 162-175. https://doi.org/10.1016/j.irfa.2015.05.024

Li, L. (2019b). Is there a trade-off between accrual-based and real earnings management? Evidence from equity compensation and market pricing. Finance Research Letters, 28, 191-197. https://doi.org/10.1016/j.frl.2018.04.021

Li, V. (2019a). The effect of real earnings management on the persistence and informativeness of earnings. The British Accounting Review, 51, 402-423. https://doi.org/10.1016/j.bar.2019.02.005

Madhogarhia, P., Sutton, N. K., \& Kohers, T. (2009). Earnings management practices among growth and value firms. Applied Financial Economics, 19(22), 1767-1778. https://doi.org/10.1080/09603100903018745

Mardini, G. H., Crawford, L., \& Power, D. M. (2012). The impact of IFRS 8 on disclosure practices of Jordanian listed companies. Journal of Accounting in Emerging Economies, 2(1), 67-90.

Mostafa, W., \& Ibrahim, M. (2019). Firm performance and earnings management. Academy of Accounting and Financial Studies Journal, 23(3), 1-11.

Müller, V-O. (2014). The impact of board composition on the financial performance of FTSE100 constituents. Procedia - Social and Behavioral Sciences, 109, 969-975. https://doi.org/10.1016/j.sbspro.2013.12.573

Muramiya, K., \& Takada, T. (2017). A research note: Quality of financial inputs and management earnings forecast accuracy in Japan. Journal of Contemporary Accounting and Economics, 13(2), 179-191. https://doi.org/10.1016/j.jcae.2017.05.001

Naciti, V. (2019). Corporate governance and board of directors: the effect of a board composition on firm sustainability. Journal of Cleaner Production, 237(10), 117727. https://doi.org/10.1016/j.jclepro.2019.117727

Obigbemi, I. F., Omolehinwa, E. O., Mukoro, D. O., Ben-Caleb, E., \& Olusanmi, O. A. (2016, July-Sept.). Earnings management and board structure: Evidence from Nigeria. Sage Open, 1-15. https://doi.org/10.1177/2158244016667992

Okougbo, P. O., \& Okike, E. (2015). Corporate governance and earnings management: Empirical evidence from Nigeria. Corporate Ownership \& Control, 12(4), 312-326.

Pappas, K., Walsh, E., \& Xu, A. L. (2019). Real earnings management and loan contract terms. The British Accounting Review, 51(4), 373-401. https://doi.org/10.1016/j.bar.2019.03.002

Prabowo, M., \& Simpson, J. (2011). Independent directors and firm performance: A quintile regression analyst for Indonesia, Malaysia. Asian- Pacific Economic Literature, 25(1), 121-132.

Priharta, A., \& Rahayu, D. P. (2019). Determinants of earnings management and its implications on the integrity of the financial statements. International Conference on Economics, Management and Accounting (ICEMA), KnE Social Sciences, 974-995. https://doi.org/10.18502/kss.v3i26.5425

Rashid, A. (2018). Board independence and firm performance: Evidence from Bangladesh. Future Business Journal, 4, 34-49. https://doi.org/10.1016/j.fbj.2017.11.003 
Saona, P., \& Muro, L. (2019). Firm-and country-level attributes as determinants of earnings management: An analysis for Latin American firms. Emerging Markets Finance and Trade, 54(12), 2736-2764. https://doi.org/10.1080/1540496x.2017.1410127

SEC. (2003). Code of Corporate Governance for Public Companies. Abuja: Securities and Exchange Commission.

SEC. (2011). SEC Code of Corporate Governance for Public Companies. Abuja: Securities and Exchange Commission. Retrieved from https://laws.lawnigeria.com/2019/03/18/sec-code-of-corporate-governance-for-public-companies-2011/

Sianturi, J. A. T. P., Wahyudi, S., Pangestuti, I. R. D., \& Utomo, M. N. (2020). Managerial opportunistic behavior and firm value: Empirical study of manufacturing companies in Indonesia. Management Science Letters, 10, 2553-2560.

Tsalavoutas, T., \& Dionysiou, D. (2014) .Value relevance of IFRS mandatory disclosure requirements. Journal of Applied Accounting Research, 15(1), 22-42.

Ubesie, M. C., Ogbu, S., \& Mbah, C. C. (2019). Effect of accruals earnings management on share price of quoted Nigerian firms. International Journal of Finance and Banking Research, 5(4), 105-113.

Yang, Y., \& Abeysekera, I. (2019). Duration of equity overvaluation and managers' choice to use aggressive underlying earnings disclosure and accrual based earnings management: Australian evidence. Journal of Contemporary Accounting \& Economics, 15(2), 167-185. https://doi.org/10.1016/j.jcae.2019.04.004

Zabri, S. M., Ahmad, K., \& Wah, K. K. (2016). Corporate Governance Practices and Firm Performance: Evidence from Top 100 Public Listed Companies in Malaysia. Procedia Economics and Finance, 35, 287-296. https://doi.org/10.1016/S2212-5671(16)00036-8

Zalata, A. M., Tauringana, V., \& Tingbani, I. (2018). Audit committee financial expertise, gender, and earnings management: Does gender of the financial expert matter?. International Review of Financial Analysis, 55, 170-183. https://doi.org/10.1016/j.irfa.2017.11.002

\section{Copyrights}

Copyright for this article is retained by the author(s), with first publication rights granted to the journal.

This is an open-access article distributed under the terms and conditions of the Creative Commons Attribution license (http://creativecommons.org/licenses/by/4.0/). 